\title{
COMMENT
}

\section{ONE ACRE MINIMUM LOT SIZE REQUIREMENT IN ZONING ORDINANCE HELD TO BE UNCONSTITUTIONAL}

The growing movement of population from urban to suburban areas poses difficult problems for the suburban community. The immediate effect is an increased load on existing facilities and services. ${ }^{I}$ As the influx continues, the need for additional facilities and services develops. Thus, new schools, roads and sewers will be required. More police and firemen must be employed. Recreation areas must be developed. ${ }^{2}$ Time will be required to meet these needs and a certain amount of planning will be essential if waste and inefficiency on the one hand or a breakdown of municipal functions on the other are to be avoided. Unfortunately, new housing does not increase the assessed value of the real estate upon which it is situated sufficiently to yield the taxes necessary to offset the additional community expenses. ${ }^{3}$ The result is a rising local tax rate. ${ }^{4}$ And not only must the older resident pay a higher tax bill, but he may also find the way of life in his community changed in a manner not in keeping with his expectations. ${ }^{5}$

Faced with these pressures, it is not surprising that the community resorts to zoning as a method of alleviating its problems, ${ }^{5 a}$ although the

1. See Isard \& Coughlin, Municipal Costs and Revenues Resulting From Community Grozeth Part 1 Residential Communities, 22 Journal OF THE AMERICAN INSTITUTE OF PLANNERS 122 (1956).

2. Ibid. "Caught in this choatic web of problems are most smaller communities, particularly those peripheral to central cities. Their rapid expansion in the last decades has forced them to provide new facilities such as streets and highways, sewerage treatment plants, storm and sanitary sewers, and schools. In addition, they have been forced to bear the burden of increased fire, police, health, welfare, and recreation services." Ibid.

3. See Zimmer \& Hawley, Home Ozeners and Attitude Toward Tax Increase, 22 JouRnal OF THE AMERTCAN INSTITUTE OF PLANNERS 65 (1956).

4. Ibid.

5. See Bauer, Do Americans Hate Cities?, 23 Journal of the AmErican InstiTUTE OF PLANNERS 2 (1957). Of course, owners of large undeveloped tracts may find that community growth greatly increases the value of their land and hence they may be willing to undergo a change in community atmosphere. Owners of small residential lots, on the other hand, may not only find the community change distasteful but may also find that a nearby development of lower cost homes reduces the resale value of their residences.

5a. In a building market favoring low cost housing, minimum acreage requirements may retard growth in a community, but essentially such a restriction is not a timing device, i.e., one which regulates the amount of growth which a community is to enjoy in a given period. An example of a timing device is an ordinance permitting issuance of only a certain number of building permits in a given period. Accordingly, minimum acreage requirements cannot readily be justified on the ground that they enable the 
justification for its doing so may have to be distinguished from the motives leading to its action. For example, it is doubtful that the mere fact that growth leads to an increased tax rate justifies imposition of restrictions upon the use of property. ${ }^{6}$ On the other hand, the fact that the community may have to build sewers, schools or roads hurriedly and haphazardly if there is a lack of planning, and that growth, if uncontrolled, would affect adversely the legitimate interests of the residents of a community in having a healthful and safe place to live, may adequately support an exercise of police power. ${ }^{7}$ Despite this necessary distinction, some zoning ordinances are hastily drawn and ill considered, enacted mainly to exclude rather than insure that growth is orderly and planned. ${ }^{8}$ Others, however, are based on careful studies of existing conditions in the community and the manner in which growth can best be accommodated.

Various types of restrictions may be incorporated in a zoning ordinance. Among these are minimum cost requirements, minimum floor space requirements and minimum lot size restrictions. Of these, minimum cost and floor space requirements, with few exceptions, have been found unreasonable by the courts. ${ }^{9}$ Minimum lot size requirements have, on the other hand, received widespread judicial approbation, although the number of cases in which an acre or larger minimum has figured has not been

community to smooth out its growth curve, thereby permitting it to more readily adapt to its increasing burdens. Whatever the justification of these restrictions, it must lie in the direction of advantages to be gained from a regulation of ultimate population density. "Municipal power to zone stems directly from state enabling acts. The majority of the acts closely follow the Standard State Zoning Enabling Act of the Department of Commerce." Haar, In Accordance With a Comprehensive Plan, 68 HARV. L. REv. 1154, 1155-56 (1955).

6. See Haar, In Accordance With a Comprehensive Plan, 68 HARv. L. Rev. $1154-58$ (1955) ; Note, 50 CoLuM. L. Rev. 202, 207 (1950). It is doubtful that most communities and courts distinguish between community planning through zoning the purpose and effect of which is to attempt to balance community growth with real estate valuation so as to prevent an upward movement of taxes and that which is direct solely towards rational land use and the provision of facilities in an orderly and efficient manner. The two tend to merge together with a third interest, that of maintaining an attractive community. It is beyond the scope of this Comment to attempt to do more than point out that a court, faced with the problem of evaluating the constitutionality of a zoning ordinance, must decide which of these purposes and effects it will regard as proper.

7. See Black, Planning for the Smatl American Ciry 36, 37 (rev. ed. 1944). "Zoning should be fitted to a community only after the most exhaustive study of that community's individual requirements and potentialities." Id. at 36 . See also Gallion, THE URBan PATTERN 240 (1950).

8. See Sayre, Aesthetics and Property Values: Does Zoning Promote the Public Welfare?, 35 A.B.A.J. 471 (1949). The test should be that a zoning ordinance is designed for the public interest in private property rather than for the selfish interests of the individual owners. Id. at 472 . A common thread running through those decisions which hold zoning ordinances unconstitutional is that the ordinances seemed to be motivated by a desire of the residents to remain exclusive. See Note, 50 Colum. I. REv. 202, 214 (1950).

9. Senefsky v. Huntington Woods, 307 Mich. 728, 12 N.W.2d 387 (1943) ; Medinger Appeal, $377 \mathrm{~Pa}$ 217, 104 A.2d 118 (1951). Contra, Lionshead Lake v. Wayne Township, 10 N.J. 165, 89 A.2d 693 (1952), appeal dismissed, 344 U.S. 919 (1953). See Haar, Zoning for Minimnm Standards: The Wayne Tozenship Case, 66 HARv. L. REv. 1051, 1059-61 (1953) ; Nolan \& Horack, Hoze Small a Honse?-Zoning for Minimum Space Requirements, 67 HARv. L. REv. 967 (1954); Haar, Wayne Tozenship: Zoning for Whom?-In Brief Reply, 67 Harv. L. REv. 986 (1954). 
great, and of these, three have found the particular restriction involved unconstitutional." The most recent of these "dissents" is Bilbar Constr. Co. v. Board of Adjustment of Easttown Township,"11 in which the Pennsylvania Supreme Court found a one acre minimum to be unconstitutional because "not reasonably and clearly necessary for the health, safety or morals of that community or its inhabitants." 12

Plaintiff construction company, owner of a fifty acre tract in defendant suburban Philadelphia township, made application to construct a single family dwelling on a lot measuring 21,000 square feet. ${ }^{13}$ In accordance with the township zoning ordinance ${ }^{11}$ which classified the district within which the tract lies as " $\mathrm{A}$ " residential and imposed a one acre $(43,560$ square feet) minimum area requirement upon lots in the district, ${ }^{15}$ the township zoning officer denied the application. The township board of adjustment sustained the denial as did the county court of common pleas. ${ }^{16}$ In reversing on appeal, the state supreme court noted that the plaintiff's tract is in a residential area, though the township is largely rural and agricultural in nature. ${ }^{17}$ On land across the road from the tract, Tredyffrin Township, adjoining Easttown Township, imposes an 18,000 square feet minimum area requirement, ${ }^{18}$ and a small business district is four hundred feet away. ${ }^{19}$ Without relating these facts to its result, the court concluded that the one acre minimum would make it "financially impossible for the vast majority of young married couples and for the people of medium income to purchase or own a home in that district. . . ."20

10. See Haar, supra note 9, at 1058-59. For cases, see notes $11,32,34,35,38,39$, 41, 43 infra. See also Application of Davis, Legal Inteligencer, Nov. 14, 1957, p. 1, col. 3 ; cf. Bogert v. Washington Township, 135 A.2d 1 (N.J. 1957).

11. Civil No. 193, Sup. Ct. Pa., June 28, 1957.

12. Id. at 9.

13. $I d$. at 1 .

14. "Municipal power to zone stems directly from state enabling acts. The majority of the acts closely follow the Standard State Zoning Enabling Act of the Department of Commerce." Haar, In Accordance With a Comprehensive Plan, 68 HARv. L. Rev. 1154, 1155-56 (1955). In Pennsylvania, townships of the second class are authorized to regulate: ". . the size of yards, courts and other open spaces, the density of population. ..." PA. Stat. AnN. tit. 53, §67001 (Purdon 1957).

15. Required minimum lot areas for other districts are: " $B$ " districts, 21,000 square feet; "C1" districts, 14,000 square feet; "C2" districts, 8,500 square feet; "D" districts, 5,000 square feet; "business" districts, no minimum. Bilbar Constr. Co. v. Board of Adjustment of Easttown Township, Civil No. 193, Sup. Ct. Pa., June 28, 1957, at 1.

16. $I d$. at 2 .

17. Ibid.

18. See Brief for Appellees, p. 3, Bilbar Constr. Co. v. Board of Adjustment of Easttown Township, Civil No. 193, Sup. Ct. Pa., June 28, 1957, stating that at one time land in Tredyffrin immediately to the north of plaintiff's lot was owned by plaintiff, and through the efforts of plaintiff, the minimum area restriction was down-zoned from 30,000 square feet to 18,000 square feet.

19. "The lot for which the building permit is sought is about 400 feet by straight line and 1300 feet by roads from a business district." Id. at 17.

20. Bilbar Constr. Co. v. Board of Adjustment of Easttown Township, Civil No. 193, Sup. Ct. Pa., June 28, 1957, at 9. 
Comprehensive zoning, ${ }^{21}$ in principle, is not violative of the due process clause of the fourteenth amendment, ${ }^{22}$ but in each case restrictions imposed by a zoning ordinance must bear a reasonable relation to the health, morals, safety or welfare of the community or its inhabitants..23 Several jurisdictions, ${ }^{24}$ including the District of Columbia, ${ }^{25}$ regard protection of aesthetic values as a proper exercise of the police power. Pennsylvania, however, apparently does not accept this position, ${ }^{26}$ and with regards to zoning has stated that "neither aesthetic reasons nor the conservation of property values or [sic] stabilization of economic values in a township are, singly or combined, sufficient" to sustain a zoning ordinance. ${ }^{2 \tau}$ Prior to the Easttozen Tozenship case, Pennsylvania had not ruled on the constitutionality of a one acre minimum requirement, but had upheld half acre and lesser restrictions, explicitly or impliedly. ${ }^{28}$ In other leading cases, its supreme court has rejected a sliding scale minimum floor space requirement ${ }^{29}$ and a set-back requirement regarded as discriminatory. ${ }^{30}$

Other jurisdictions which have ruled upon the constitutionality of one acre or larger minimum area restrictions have generally sustained them, though for a variety of reasons. ${ }^{31}$ Massachusetts declared a one acre requirement valid in a township of 1300 people situated twelve miles from Boston,,$^{32}$ though with a caveat that an ordinance exclusionary in purpose would be unconstitutional. ${ }^{33}$ New York has upheld a two acre minimum ${ }^{34}$

21. For a definition of a comprehensive zoning plan, see Kutcher v. Town Planning Comm'n, 138 Conn. 705, 88 A.2d 538 (1952) ; 8 MCQUILLAN, MUNICIPAL CoRPORATIONS $\$ 25.79$ ( $3 \mathrm{~d}$ ed. 1950 ).

22. Village of Euclid v. Ambler Realty Co., 272 U.S. 365 (1926).

23. See White's Appeal, 287 Pa. 259, 265, 134 Atl. 409, 411 (1926).

24. See Jacobsen v. Village of Wilmette, 403 I11. 250,85 N.E.2d 753 (1949); State ex rel. Saveland Park Holding Corp. v. Wieland, 269 Wis. 262, 69 N.W.2d 217 (1955). In Wulfshon v. Burden, 241 N.Y. $288,300,150$ N.E. 120,123 (1925), the court stated that aesthetic considerations influenced many courts to declare zoning ordinances constitutional, even though these same courts based their decision on other grounds. See also an advisory opinion by the highest Massachusett court, 128 N.E.2d 557 (Mass. 1955). For the role which aesthetics have played in California law, see Rodda, The Accomplishment of Aesthetic Purposes Under the Police Power, 27 So. CaLIF. L. REv. 149 (1954). For the argument that aesthetic values should be included as one of the valid subjects of the police power, see Sayre, supra note 8.

25. See Berman v. Parker, 348 U.S. 26 (1954) (dictum).

26. Medinger Appeal, $377 \mathrm{~Pa}$. 217, 226, 104 A.2d 118, 122 (1954); White's Appeal, $287 \mathrm{~Pa} .259,266,134$ Atl. 409, 412 (1926) ; accord, Lord Appeal, $368 \mathrm{~Pa} .121,128$, 81 A.2d 533, 536 (1951). But see Kerr's Appeal, 294 Pa. 246, 250, 144 Atl. 81, 83 (1928).

27. Medinger Appeal, 377 Pa. 217, 226, 104 A.2d 118, 122 (1954).

28. Volpe Appeal, $384 \mathrm{~Pa} .374,121$ A.2d 97 (1956); Elkins Park Improvement Ass'n Zoning Case, $361 \mathrm{~Pa}$. 322, 64 A.2d 783 (1949); Brosnan's Appeal, $330 \mathrm{~Pa}$. 161, 198 Atl. 629 (1938).

29. Medinger Appeal, 377 Pa. 217, 104 A.2d 118 (1954).

30. White's Appeal, 287 Pa. 259, 134 Atl. 409 (1926).

31. By considering restrictions of one acre or larger together, it is not meant to imply that all restrictions of one acre or more present the same problem of justification. Obviously, the problem is one of degree, and the larger the restriction, in general the more difficult it will be to justify.

32. Simon v. Needham. 311 Mass. 560, 42 N.E.2d 516 (1942).

33. Id. at 565,42 N.E. $2 d$ at 518 .

34. Dillard v. Village of North Hills, 276 App. Div. 969, 94 N.Y.S.2d 715 (2d Dep't 1950), reversing 195 Misc. 875, 91 N.Y.S.2d 542 (Sup. Ct. 1949). 
and one of 40,000 square feet. ${ }^{35}$ The former decision rested in part on the fact that the disputant of the constitutionality of the ordinance had already made a sizeable profit from a sale of part of the land he had recently purchased in the district, and was seeking to increase his profit on the remainder through a down zoning. ${ }^{36}$ The 40,000 square feet requirement was sustained in a small village bounded on three sides by water, the court taking note of the fact that there are inherent advantages in an attractive residential area. ${ }^{37}$ Missouri has declared a three acre restriction valid ${ }^{38}$ and New Jersey one of five acres. ${ }^{39}$ The New Jersey decision can be partially explained by the New Jersey Constitution which makes it obligatory for courts to construe the constitutionality of zoning ordinances liberally in favor of the municipality. ${ }^{40}$ On the other hand, Illinois has voided a two and one-half acre requirement ${ }^{41}$ on the ground, inter alia, that none of the surrounding plots met the requirements of the zoning ordinance. ${ }^{42}$ And Michigan struck down a three acre minimum because the greater part of the community was zoned for three acres while the next lower classification was 10,000 square feet. ${ }^{33}$

Three interests emerge in a minimum acreage zoning case: those of the landowner, of the community and its other inhabitants, and of the non-residents of the community seeking to migrate to the locale. ${ }^{44}$ The community in its zoning ordinance may be expected to give adequate protection to its own interest and those of its inhabitants, apart at least from that of the landowner challenging the ordinance. The role of the court must therefore be, within the framework of the police power dogma, to insure that the minimum area requirement is not unreasonably detrimental to the interests of the challenging landowner and non-residents of the community. The latter, who have had no voice in the enactment of the ordinance and who will not be parties to an action testing its constitutionality, must as a rule depend upon the landowner to adequately represent their position. Ideally, the court would have at its disposal in the making of its determination as to the reasonableness of the ordinance 1950).

35. Gignoux v. Village of King's Point, 199 Misc. 485, 99 N.Y.S.2d 280 (Sup. Ct.

36. Dillard v. Village of North Hills, 276 App. Div. 969, 94 N.Y.S.2d 715 (2d Dep't 1950), reversing 195 Misc. 875, 91 N.Y.S.2d 542 (Sup. Ct. 1949).

37. See Gignoux v. Village of King's Point, 199 Misc. 485, 491, 99 N.Y.S.2d 280, 286 (Sup. Ct. 1950).

38. Flora Realty and Inv. Co. v. City of Ladue, 362 Mo. 1025, 246 S.W.2d 771, appeal dismissed, 344 U.S. 802 (1952).

39. Fisher v. Bedminster, 21 N.J. Super. 81,90 A.2d 757 (L. 1952).

40. Id. at 84,90 A.2d at 759 .

41. County of Du Page v. Halkier, I I11. 2d 491, 115 N.E.2d 635 (1953).

42. Id. at 495-96, 115 ,N.E.2d at 637-38.

43. Hitchman v. Township of Oakland, 329 Mich. 331, 336-37, 45 N.W.2d 306, 309 (1951).

44. "Cities are not surrounded by walls, [sic] they are each a part of their region and each is obliged to plan the spaces within its boundaries as an integral part of the plan for spaces outside its boundaries." Gallion, ThE URban PaTTERN 235 (1950). 
a regional plan against which to measure the community plan. ${ }^{45}$ This plan would, by its nature, have to take into account more than the local communities' interests, and would permit all residents of the metropolitan area to have some voice in its development. Since few such plans have been adopted, however, the court will normally have to depend on the parties to the controversy-the landowner and the township-to assist it in fulfilling its role. Thus, the framers of the ordinance should come forward to demonstrate with evidence the factual basis upon which the ordinance is founded: the character of the neighborhood, the lay of the land, the existing and proposed transportation and sewerage networks, the capacity of the school system and the manner in which it will be augmented, the level of police and fire protection and other municipal services, and the relation which the proposed population density bears to each of these. ${ }^{46}$ They should be able to show that the community has not set aside an unreasonably large portion of its available land for the highest minimum acreage requirement, but has made allowance for various densities, and that in general it has provided for orderly growth rather than has effectively blocked growth. In opposition, the landowner, on his own behalf and on behalf of the non-residents of the community, may introduce evidence tending to indicate that the plan adopted does not bear a reasonable relation to these factors or was framed without consideration of them. Assuming a carefully drawn plan, well conceived from the standpoint of land use and community planning, rather than from the standpoint alone of the effect that growth may have upon the community tax rate, the court should not substitute its judgment for that of the collective judgment of the residents of the community, although it would have arrived at a different conclusion in their place. ${ }^{47}$

In Easttozen Tozenship neither party introduced any substantial amount of evidence. ${ }^{48}$ Thus unaided, the court must decide what presumption of constitutionality, if any, should attach to the ordinance. A suggested approach and the one the Pennsylvania court apparently adopted, is that a presumption of constitutionality shall attach unless the ordinance is "exclusionary" in effect, in which case the presumption shifts to one of unconstitutionality. ${ }^{49}$ Since any minimum area requirement is to some extent exclusionary, such a finding in a particular case is at best one that the

45. See Haar, Land Use Planing, 105 U. PA. L. Rev. 515, 524 (1957) ; Haar, Zoning for Minimum Standards: The Wayne Tozmship Case, 66 HARv. L. Rev. 1051, 1062 (1953).

46. See note 7 supra.

47. Silver v. Zoning Bd. of Adjustment, $381 \mathrm{~Pa} .41,112$ A.2d 84 (1955); Gratton v. Conte, $364 \mathrm{~Pa}$. 578, 73 A.2d 381 (1950); Liggett's Petition, $291 \mathrm{~Pa}$. 109, 139 Atl. 619 (1927); Kistler v. Swarthmore Borough, 134 Pa. Super. 287, 4 A.2d 244 (1939).

48. See Record, Bilbar Constr. Co. v. Board of Adjustment of Easttown Township, Civil No. 193, Sup. Ct. Pa., June 28, 1957.

49. "If after investigating there is doubt as to whether the statute is enacted for a recognized police object, or if, conceding its purpose, its exercise goes too far, it then becomes the judicial duty to declare the given exercise of the police power invalid." White's Appeal, 287 Pa. 259, 265, 134 Atl. 409, 411 (1926). 
restriction was unduly exclusionary.50 However, there may be facts of which the court could take judicial notice which would serve as guides to such a conclusion. For example, the court could notice the distance of the community from the center of the metropolitan area, and the rate and direction of population movements from that center. These factors would indicate roughly the rate of growth the community might expect apart from any zoning restrictions. This, compared with the community's present and planned density, would suggest the extent to which the community's zoning would inhibit the natural rate of growth. As a guide to the reasonableness of the inhibition, the court could then notice the densities and zoning restrictions of neighboring communities. Thus, a markedly lower planned density in the community in question in comparison with its neighboring communities would raise an inference of exclusion. ${ }^{51}$ As a further suggestion the court could take notice of the average cost of a home on the ground zoned, for example, one acre in the community in question. If this cost would be prohibitive for all but a small percentage of the population of the metropolitan area, this would further strengthen the inference of exclusion.52 In the Easttowen Township case, the court regrettably reached its conclusion without an analysis of this sort, thus providing no assistance to communities or landowners in future cases.

50. The court might wish to give blanket approval to all minimums of, for example, less than half an acre as a matter of administrative expediency, for the chances that such restrictions could not be justified are slight. It would then only consider the "exclusionary" aspects of restrictions of a half acre or larger.

51. The converse, i.e., that if neighboring communities have adopted similar restrictions, that of the community in question is not exclusionary, does not follow. Frequently, neighboring communities will all adopt the same high restriction. 